\title{
Timing of intubation, beds in intensive care and inter-hospital transfer: rings of a complex chain during pandemic conditions
}

\author{
Filippo Sanfilippo ${ }^{1 *}$, Luigi La Via' ${ }^{1}$ Giuseppe Carpinteri ${ }^{2}$ and Marinella Astuto ${ }^{1}$
}

Dear Editor,

Gonzalez et al. published a prospective study focusing on timing of intubation and outcome of patients with coronavirus disease (COVID-19) [1]. The authors considered early intubation if this occurred within the first $48 \mathrm{~h}$ from the first respiratory support, and compared this strategy $(n=140)$ with a group that received delayed intubation $(n=65)$. The authors reported that delayed intubation caused a significant increase in hospital mortality (hazard ratio 2.4 in multivariate analysis); moreover, survivors in the delayed intubation group had worse pulmonary sequelae as evaluated by CT scan and DLCO.

These results are interesting, and other recent evidence is pointing towards benefits of early intubation in COVID-19 patients [2], in contrast with previous findings published by the journal [3]. Indeed, a recent metaanalysis investigated this topic including 12 studies and almost 9000 COVID-19 patients. The pooled evidence showed a trend towards increased all-cause mortality in patients receiving early invasive mechanical ventilation $(45.4 \%)$ as compared with those with late intubation (39.1\%; Risk Ratio 1.07, 95\% CI 0.99-1.15, $p=0.08$ ) [3].

How to interpret such discrepancies? We believe that timing of intubation is only one of the rings of a complex chain during pandemic conditions (Fig. 1). Indeed, while emergency and critical care physicians strive to deliver the most appropriate treatment for COVID-19 (and

*Correspondence: filipposanfi@yahoo.it

${ }^{1}$ Department of Anaesthesia and Intensive Care, A.O.U. Policlinico-San Marco, Via Santa Sofia 78, 95100 Catania, Italy

Full list of author information is available at the end of the article non COVID-19!) patients, the decision to intubate early should be always balanced with other local factors, and in particular with the availability of intensive care unit (ICU) beds.

The surge in hospital admissions caused by the current pandemic wave is causing serious issues of bed availability in several hospitals. It is not uncommon that the closest ICU bed available is hundreds of kilometres away, in a different province/region. Thus, the decision to intubate may sometimes imply the need for a long inter-hospital transfer. To make things more complex, the prompt availability of specialized ambulances for transfer of critically ill patients is seriously challenged too. Indeed, ambulance services are overloaded by demands and rows of ambulances with COVID-19 patients waiting outside the emergency departments are reported with almost daily frequency in each country. Under certain emergency circumstances, even military healthcare teams have been deployed to assist the ambulance service [4]. Therefore, it frequently happens that intubated patients remain in the Emergency Department (ED) for several hours before the transfer can be accomplished. Finally, even if an ICU bed has been found and a specialized ambulance is available, the risks associated with long inter-hospital transfers of COVID-19 patients should not be underestimated [5].

While we applaud the authors for their well-conducted study, we think that all the analyses performed on timing of intubation of COVID-19 under challenging pandemic conditions should also account for the time occurring from intubation to the effective ICU admission. Only at this time, specialized critical care treatments may be fully delivered with a better staff-to-patient ratio, the original author(s) and the source, provide a link to the Creative Commons licence, and indicate if changes were made. The images or other third party material in this article are included in the article's Creative Commons licence, unless indicated otherwise in a credit line to the material. If material is not included in the article's Creative Commons licence and your intended use is not permitted by statutory regulation or exceeds the permitted use, you will need to obtain permission directly from the copyright holder. To view a copy of this licence, visit http://creativecommons.org/licenses/by/4.0/. The Creative Commons Public Domain Dedication waiver (http://creativeco mmons.org/publicdomain/zero/1.0/) applies to the data made available in this article, unless otherwise stated in a credit line to the data. 


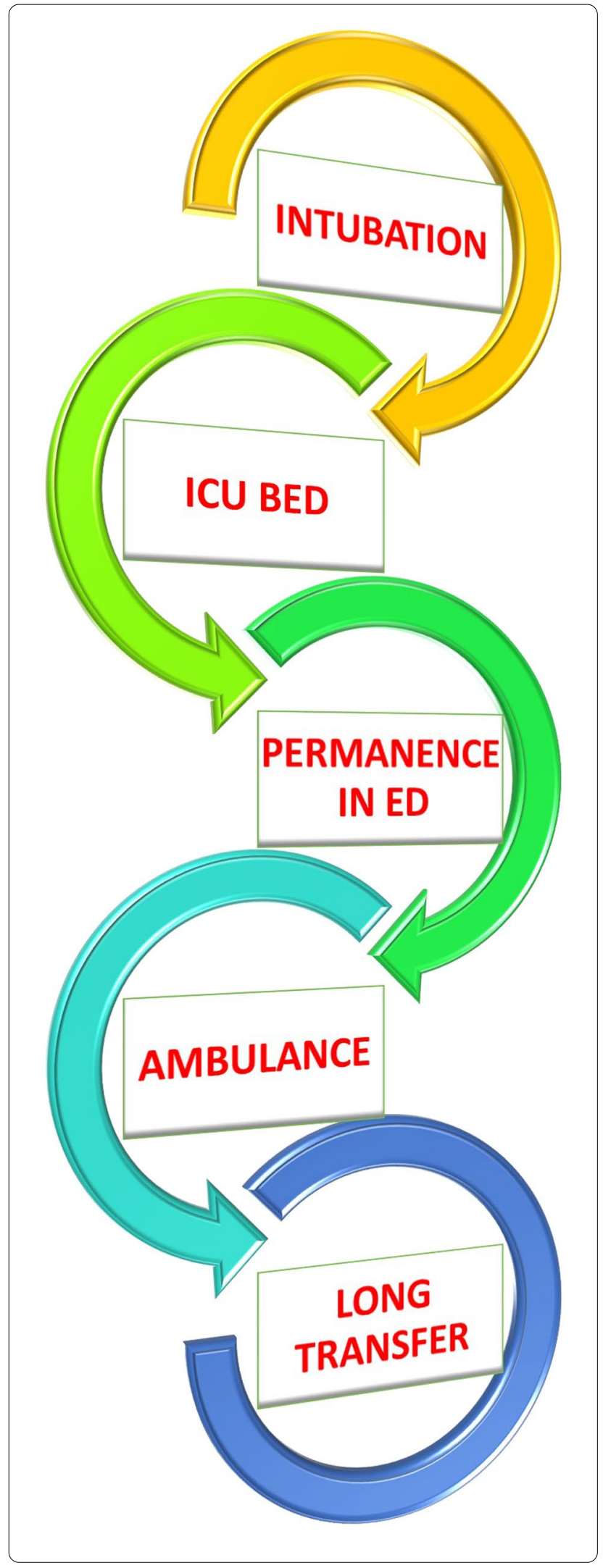

4 Fig. 1 Rings of a complex chain in decision-making for the timing of intubation during pandemic conditions. ED emergency department, ICU intensive care unit

use of high-performing ventilators and adequate monitoring systems. In summary, it is possible that patients exposed to long inter-hospital transfer and/or delayed ICU admission may not similarly benefit of a strategy of early intubation.

\section{Abbreviations}

COVID-19: Coronavirus disease 2019; ED: Emergency Department; ICU: Intensive Care Unit.

\section{Acknowledgements}

Not applicable.

\section{Authors' contributions}

All the authors read and discussed the critical issues of the manuscript by Gonzalez et al. FS wrote the draft of the letter to the Editor, FS and LLV reviewed the evidence on timing for intubation in COVID-19 patients, all the authors reviewed the evidence regarding the ambulance transfer of patients with COVID-19, GC and MA edited the draft. FS submitted the letter. All authors read and approved the final manuscript.

\section{Funding}

Not applicable.

\section{Availability of data and materials}

Not applicable.

\section{Declarations}

Ethical approval and consent to participate

Not applicable.

\section{Consent for publication}

Not applicable.

\section{Competing interests}

The authors have read BioMed Central's guidance on competing interests, and they declare no competing interests.

\section{Author details}

${ }^{1}$ Department of Anaesthesia and Intensive Care, A.O.U. Policlinico-San Marco, Via Santa Sofia 78, 95100 Catania, Italy. ${ }^{2}$ Department of Emergency Medicine, A.O.U. Policlinico-San Marco, Via Santa Sofia 78, 95100 Catania, Italy.

Received: 14 January 2022 Accepted: 31 January 2022

Published online: 12 February 2022

\section{References}

1. González J, Benítez ID, de Gonzalo-Calvo D, Torres G, de Batlle J, Gómez S, Moncusí-Moix A, Carmona P, Santisteve S, Monge A, et al. Impact of time to intubation on mortality and pulmonary sequelae in critically ill patients with COVID-19: a prospective cohort study. Crit Care. 2022;26(1):18.

2. Fayed M, Patel N, Yeldo N, Nowak K, Penning DH, Vasconcelos Torres F, Natour AK, Chhina A. Effect of intubation timing on the outcome of patients with severe respiratory distress secondary to COVID-19 pneumonia. Cureus. 2021;13(11):e19620. 
3. Papoutsi E, Giannakoulis VG, Xourgia E, Routsi C, Kotanidou A, Siempos II. Effect of timing of intubation on clinical outcomes of critically ill patients with COVID-19: a systematic review and meta-analysis of non-randomized cohort studies. Crit Care. 2021;25(1):121.

4. James RH, Doyle CP, Cooper DJ. Descriptive record of the activity of military critical care transfer teams deployed to London in April 2020 to undertake transfer of patients with COVID-19. BMJ Mil Health. 2020 https://doi.org/10.1136/bmjmilitary-2020-001619.

5. Allen R, Wanersdorfer K, Zebley J, Shapiro G, Coullahan T, Sarani B. Interhospital transfer of critically ill patients because of coronavirus disease 19-related respiratory failure. Air Med J. 2020;39(6):498-501.

\section{Publisher's Note}

Springer Nature remains neutral with regard to jurisdictional claims in published maps and institutional affiliations.

- fast, convenient online submission

- thorough peer review by experienced researchers in your field

- rapid publication on acceptance

- support for research data, including large and complex data types

- gold Open Access which fosters wider collaboration and increased citations

- maximum visibility for your research: over $100 \mathrm{M}$ website views per year

At BMC, research is always in progress.

Learn more biomedcentral.com/submissions 